DOI: $10.19195 / 0524-4544.322 .9$

\author{
ELŻBIETA KLAT-GÓRSKA \\ Uniwersytet Wrocławski \\ e-mail: elzbieta.klat-gorska.uwr.edu.pl
}

ANDRZEJ NIKIFORÓW

Dolnośląski Urząd Wojewódzki we Wrocławiu

e-mail: nikiforow@live.com

\title{
Glosa do wyroku \\ Naczelnego Sądu Administracyjnego \\ z dnia 19 lipca 2016 r., II OSK 2762/14*
}

\section{Teza}

W sytuacji, gdy przepisy prawa przewidują załatwienie sprawy przez wydanie decyzji administracyjnej, udzielenie podmiotowi żądającemu rozstrzygnięcia o jego sytuacji prawnej wyłącznie samego wyjaśnienia sprowadzającego się do opisu faktów, należy $[. .$.$] rozumieć jako uchylenie się od wydania decyzji administracyjnej.$ Okoliczność, iż organ wadliwie odstąpił od obowiązku rozstrzygnięcia o dopuszczalności prowadzenia postępowania, nie mogła prowadzić jednak do nadania podjętej przez organ czynności o charakterze informacyjnym treści odmiennej od przyjętej (postanowienie o odmowie wszczęcia postępowania), stanowić bowiem mogła jedynie podstawę do wymuszenia na organie wydania wymaganego aktu procesowego poprzez wystąpienie przez stronę z odpowiednim środkiem prawnym przeciwdziałającym niezgodnemu z prawem działaniu organu administracji publicznej — złożenie zażalenia do organu wyższego stopnia (art. 37 § 1 k.p.a.), a następnie skargi na bezczynność do sądu administracyjnego (art. $3 \S 2$ pkt 8 p.p.s.a.). Wnoszący skargę kasacyjną [...] powinien był skorzystać tym samym z powyższych środków prawnych, które w odróżnieniu od próby „zaskarżenia” pisma środkami

* LEX nr 2102235. 
odwoławczymi wymienionymi w kodeksie postępowania administracyjnego, służyłyby — jak się wydaje — efektywniej rozwiązaniu sporu prawnego [... $]^{1}$.

Glosowanym wyrokiem NSA oddalił skargę kasacyjną od wyroku Wojewódzkiego Sądu Administracyjnego w Poznaniu z dnia 25 czerwca 2014 r. (II SA/Po 260/14) w sprawie skargi na postanowienie Wielkopolskiego Wojewódzkiego Inspektora Nadzoru Budowlanego w Poznaniu w przedmiocie stwierdzenia niedopuszczalności zażalenia. Wyrok ten został wydany w następującym stanie faktycznym i prawnym sprawy. Wnioskodawca wystąpił do Powiatowego Inspektora Nadzoru Budowlanego w K. z żądaniem wszczęcia postępowania administracyjnego w sprawie, jak określił, warunków bezpieczeństwa ludzi i mienia w rozwiązaniach przyjętych w projekcie budowlanym, przy wykonywaniu robót budowlanych oraz utrzymywaniu obiektów budowlanych budynku wielorodzinnego przy ul. (...) w K. W uzasadnieniu tego żądania wskazano na nieodpowiedni stan instalacji nawiewno-wywiewnej w budynku oraz nadmierny hałas dochodzący z pobliskiej drogi. Powiatowy Inspektor Nadzoru Budowlanego w K. powiadomił wnioskodawcę — w piśmie z dnia 14 maja 2013 r. — o braku podstaw do wszczęcia postępowania administracyjnego we wskazanej sprawie. Organ wyjaśnił, że w dniu 30 kwietnia 2013 r. została przeprowadzona kontrola w budynku przy ul. (...) w K. ze szczególnym uwzględnieniem lokalu nr (...), należącego do wnioskodawcy. W jej trakcie stwierdzono, że w kuchni i łazience jest ciąg w przewodach wentylacyjnych, co potwierdził także mistrz kominiarski. Nie wykryto, aby spaliny z kotłów gazowych były odprowadzane do jednego ciągu nawiewno-wywiewnego w pionie trzech kondygnacji, co również potwierdza oświadczenie mistrza kominiarskiego.

Na to pismo Inspektora Nadzoru Budowlanego wnioskodawca wniósł zażalenie, przyjmując, iż stanowi ono postanowienie o odmowie wszczęcia postępowania administracyjnego. Jednocześnie wystąpił z wnioskiem o przywrócenie terminu do wniesienia zażalenia. Postanowieniem z dnia (...) stycznia 2014 r. Wielkopolski Wojewódzki Inspektor Nadzoru Budowlanego na podstawie art. 134 ustawy z dnia 14 czerwca 1960 r. - Kodeks postępowania administracyjnego ${ }^{2}$ stwier- $^{-}$ dził niedopuszczalność odwołania. W uzasadnieniu organ wyjaśnił, że wniesione przez skarżącego zażalenie jest niedopuszczalne, gdyż w tej sprawie brakuje przedmiotu zaskarżenia. Wskazał przy tym, że zaskarżone pismo z dnia 14 maja 2013 r. nie zawiera elementów wymienionych w art. $124 \S 1$ i 2 k.p.a. W ocenie organu ze względu na brak rozstrzygnięcia - zwłaszcza tego, o którym mowa w art. 61a k.p.a. — nie ma ono minimum składników niezbędnych, aby można je było uznać za postanowienie. Wielkopolski Wojewódzki Inspektor Nadzoru Budowlanego podkreślił, że pełnomocnik skarżącego miał świadomość powyższego, gdyż w dniu 13 listopada 2013 r. złożył skargę na bezczynność Powiatowego

1 Teza wskazana przez glosatorów, będąca fragmentem uzasadnienia powołanego wyroku NSA z dnia 19 lipca 2016 r., II OSK 2762/14.

2 Wówczas tekst jednolity ustawy opublikowany był w Dz.U. z 2013 r. poz. 267 z późn. zm. Obecnie tekst jedn. Dz.U. z 2016 r. poz. 23 z późn. zm. (dalej: k.p.a.). 
Inspektora Nadzoru Budowlanego w K. w zakresie rozpatrzenia wniosku z dnia 2 kwietnia 2013 r. Skarga ta została następnie uznana za uzasadnioną, o czym powiadomiono skarżącego pismem z dnia 16 grudnia $2013 \mathrm{r}$.

Oddalając skargę wnioskodawcy na postanowienie Wielkopolskiego Wojewódzkiego Inspektora Nadzoru Budowlanego w Poznaniu, Wojewódzki Sąd Administracyjny w Poznaniu w wyroku z dnia 25 czerwca 2014 r. (II SA/Po 260/14) wyjaśnił, że zgodnie z art. $141 \S 1$ k.p.a. na wydane w toku postępowania postanowienia stronie przysługuje zażalenie, gdy kodeks tak stanowi. Oznacza to, że strona może wnieść skutecznie zażalenie tylko wtedy, gdy chce ona zakwestionować akt organu administracji publicznej przybierający postać postanowienia, a nadto ustawodawca wyraźnie przewidział, że dane postanowienie jest zaskarżalne zażaleniem. W ocenie sądu pierwszej instancji należało stwierdzić, że omawiane pismo z dnia 14 maja 2013 r. nie zawierało wszystkich elementów wymienionych w art. 124 k.p.a., w szczególności nie posiadało jednoznacznego wskazania stron postępowania, powołania podstawy prawnej, rozstrzygnięcia, pouczenia o środkach odwoławczych przysługujących stronom oraz uzasadnienia prawnego. Okoliczności te nie były zresztą kwestionowane nawet przez skarżącego, co powinno prowadzić do wniosku, iż pismo z dnia 14 maja 2013 r. nie miało charakteru postanowienia. Przy tym sąd wyjaśnił, że pismo Inspektora miało jedynie i charakter nformacyjny, który nadał mu Powiatowy Inspektor Nadzoru Budowlanego w K.; tak odczytywał jego treść Wielkopolski Wojewódzki Inspektor Nadzoru Budowlanego w rozstrzygnięciach z dnia (...) listopada 2013 r. i z dnia (...) grudnia 2013 r., podjętych na skutek skarg skarżącego. Informacyjny charakter tego pisma nie budził także wątpliwości samego skarżącego do chwili złożenia zażalenia z dnia 18 grudnia $2013 \mathrm{r}$.

Skargę kasacyjną od powyższego wyroku złożył wnioskodawca, zaskarżając go w całości i wnosząc o jego uchylenie oraz o przekazanie sprawy do ponownego rozpoznania przez sąd pierwszej instancji. W uzasadnieniu skargi kasacyjnej skarżący podniósł, że sąd pierwszej instancji dokonał wadliwej oceny pisma z dnia 14 maja 2013 r., nadając mu jedynie informacyjny charakter, gdy w istocie było ono orzeczeniem, o którym mowa w art. $61 \mathrm{a} \S 1$ k.p.a. Skarżący przyznał, że początkowo nie traktował ww. pisma jako postanowienia — jak zauważył w uzasadnieniu wyroku sąd pierwszej instancji - lecz ten sposób myślenia się zmienił. Na tę zmianę miał wpływ wyrok Naczelnego Sądu Administracyjnego z dnia 30 października 2013 r., II OSK 1779/13, w którym zawarto tezę, iż w stosunku do postanowień znajduje zastosowanie reguła, w świetle której to nie forma, lecz treść merytoryczna decyduje o kwalifikacji prawnej aktu administracyjnego. Porównanie obu pism (skierowanego do skarżącego oraz ocenianego przez Naczelny Sąd Administracyjny) wskazywało, zdaniem wnoszącego skargę kasacyjną, że ich charakter jest podobny, i w ocenie skarżącego tak też powinny zostać one ocenione w kontrolowanym postępowaniu, biorąc pod uwagę potrzebę zapewnienia jednolitości orzecznictwa. 
Naczelny Sąd Administracyjny w glosowanym wyroku z dnia 19 lipca 2016 r., II OSK 2762/14 stwierdził, że skarga kasacyjna nie ma usprawiedliwionych podstaw. W uzasadnieniu wyroku podniesiono, że wychodząc z założenia, iż o charakterze danej czynności procesowej czy kwalifikacji aktu nie decyduje forma, lecz jego merytoryczna treść, należy przypomnieć, że zgodnie z ugruntowanym $\mathrm{w}$ orzecznictwie sądowoadministracyjnym i doktrynie prawa administracyjnego poglądem cechami konstytutywnymi aktu administracyjnego są: oznaczenie organu administracji publicznej wydającego akt, oznaczenie adresata aktu, sformułowanie rozstrzygnięcia oraz podpis osoby upoważnionej do wydania $a_{k t u}{ }^{3}$. Sąd wyjaśnił, że określone pismo może zostać uznane za akt administracyjny pod warunkiem zaistnienia w nim wszystkich wskazanych wyżej elementów konstrukcyjnych.

Z drugiej strony Naczelny Sąd Administracyjny podkreślił jednak, że o ile do pism kierowanych do organu administracji publicznej przez stronę można odnosić zasadę ograniczonego formalizmu, która sprawia, że formułowane przez stronę oświadczenia woli poddawane mogą być nawet daleko idącym wnioskowaniom interpretacyjnym, o tyle wykładnia dokumentów urzędowych, w tym aktów administracyjnych, nie powinna wychodzić poza językowe znaczenie treści wyrażonej w dokumencie przez organ. Przyjmowanie domniemania działania organu w formie procesowej (decyzji/postanowienia) z pewnością zwiększa sferę ochrony przyznawanej stronie, niemniej nie może to stać w sprzeczności z ujawnioną wolą organu i jednoznaczną treścią podjętej czynności urzędowej. Podkreślono przy tym, że w wyroku z dnia 3 marca 2016 r. (II OSK 1678/14) Naczelny Sąd Administracyjny trafnie wskazał, że odformalizowanie postępowania administracyjnego ma swoje granice, albowiem nie powinno ono otwierać drogi do takich działań, które mogą podważyć gwarancje praworządności. Przypisanie działaniu organu znaczenia odmiennego od wyrażonego przezeń w treści aktu (czynności) powinno być możliwe tylko wówczas, gdy nie odpowiada ono wyartykułowanej przez organ formie jego działania, natomiast koresponduje jednoznacznie $\mathrm{z}$ inną formą. Z tego względu jeżeli pismo organu sprowadza się do przekazania określonej osobie pewnych faktów, ponieważ organ zdaje sobie sprawę, że nie zachodzi podstawa do jego działania $\mathrm{w}$ formie procesowej i o tym tę osobę informuje, nawet zastosowanie zasady, iż postać (oznaczenie) pisma nie ma decydującego znaczenia, nie może prowadzić do wniosku, że zawarta w piśmie informacja stanowi rozstrzygnięcie $w$ rozumieniu art. $107 \S 1$ k.p.a. tylko dlatego, że adresat pisma nie zgadza się z powyższą informacją.

Naczelny Sąd Administracyjny podkreślił, że w rozpoznawanej sprawie pismo Powiatowego Inspektora Nadzoru Budowlanego w K., jak trafnie przyjął sąd

3 Zob. wyrok NSA z dnia 21 lutego 1994 r., I SAB 54/93, z glosą B. Adamiak i J. Borkowskiego, OSP 1995, nr 11, poz. 222.

${ }^{4}$ LEX nr 2066350. 
pierwszej instancji, nie zawierało rozstrzygnięcia o sytuacji prawnej skarżącego, albowiem jedynie informowało go m.in. o wynikach przeprowadzonych oględzin lokalu, a także o ocenach technicznych przyjętych przez podmioty badające działanie przewodów wentylacyjnych. Abstrahując od prawidłowości tychże ocen, należy podkreślić, że pismo miało charakter informacyjny mający na celu przekazanie skarżącemu wiedzy o wynikach kontroli. Z jego treści nie wynikała wola organu skierowana na wywołanie skutków prawnych, które w tym przypadku (art. 61a § 1 k.p.a.) należałoby łączyć z odmową wszczęcia jurysdykcyjnego postępowania administracyjnego z powodu zaistnienia uzasadnionej przyczyny sprzeciwiającej się prowadzeniu postępowania. Stwierdzenie, że w sprawie nie ma podstaw do wszczęcia postępowania, organ łączył z przedstawionymi okolicznościami potwierdzającymi sprawność funkcjonowania przewodów wentylacyjnych, co jednak było nie tyle nakierowane na zamknięcie zainteresowanemu drogi do procesowego rozstrzygnięcia przez organ nadzoru budowlanego o zasadności jego żądania, ile sprowadzało się wyłącznie do przekazania stronie wiedzy urzędowej, którą organ dysponował.

Sąd drugiej instancji wskazał, że nie może budzić wątpliwości, iż wniesione przez skarżącego pismo z dnia 2 kwietnia 2013 r., ze względu na jednoznaczność sformułowanego żądania, powinno było prowadzić do wydania przez Powiatowego Inspektora Nadzoru Budowlanego w K. stosownej decyzji procesowej (zawiadomienie o wszczęciu postępowania na wniosek/postanowienie odmawiające wszczęcia postępowania). Gdy przepisy prawa przewidują załatwienie sprawy przez wydanie decyzji administracyjnej, udzielenie podmiotowi żądającemu rozstrzygnięcia o jego sytuacji prawnej wyłącznie samego wyjaśnienia sprowadzającego się do opisu faktów, należy rozumieć jako uchylenie się od wydania decyzji administracyjnej. Okoliczność, że organ niewłaściwie odstąpił od obowiązku rozstrzygnięcia o dopuszczalności prowadzenia postępowania, nie mogło jednak prowadzić do nadania podjętej przez organ czynności o charakterze informacyjnym treści odmiennej od przyjętej (postanowienie o odmowie wszczęcia postępowania), stanowić mogło jedynie podstawę do wymuszenia na organie wydania wymaganego aktu procesowego poprzez wystąpienie przez stronę z odpowiednim środkiem prawnym przeciwdziałającym niezgodnemu z prawem działaniu organu administracji publicznej — złożeniem zażalenia do organu wyższego stopnia (art. 37 § 1 k.p.a.), a następnie skargi na bezczynność do sądu administracyjnego (art. $3 \S 2$ pkt 8 p.p.s.a.).

I. W zasługującym na aprobatę glosowanym orzeczeniu Naczelny Sąd Administracyjny odniósł się do dwóch zasadniczych kwestii proceduralnych o charakterze ogólnym, wskazując po pierwsze na kryteria kwalifikacji pism kierowanych przez organ administracji do wnioskodawcy, a po drugie - określając podstawę do wymuszenia na organie administracji wydania wymaganego aktu procesowego.

Do analizy stanowiska Naczelnego Sądu Administracyjnego przedstawionego w omawianym wyroku, dotyczącego pierwszego z wymienionych problemów, konieczne jest wskazanie, że działania prawne organów administracji publicznej 
dzieli się w doktrynie i orzecznictwie na akty prawne zmierzające bezpośrednio do wywołania skutku prawnego w sferze praw i obowiązków stron oraz na czynności faktyczne i prawne o różnym charakterze, np. merytoryczne, procesowe ${ }^{5}$. W związku z tym w sprawach indywidualnych administracja publiczna może działać nie tylko poprzez wydawanie aktów administracyjnych w formie decyzji czy postanowien, albowiem wiele istotnych pod względem prawnym spraw jest w świetle norm prawnych załatwianych w drodze podejmowanych przez właściwy organ administracji publicznej czynności materialno-technicznych ${ }^{6}$. Przedmiotem dokonanej kontroli sądowej w sprawie było postanowienie stwierdzające niedopuszczalność zażalenia, które zapadło we wstępnym etapie postępowania przed organem administracji publicznej wyższego stopnia.

Przy określaniu właściwości organu administracji publicznej do rozpatrzenia zażalenia przyjmuje się, że organem takim jest organ administracji publicznej wyższego stopnia, chyba że ustawa stanowi inaczej (zob. art. $144 \mathrm{w}$ związku z art. $127 \S 2$ k.p.a.) ${ }^{7}$. Rozpatrzenie zażalenia może zatem nastąpić po wydaniu postanowienia przez organ pierwszej instancji i wniesieniu zażalenia na to postanowienie przez uprawniony podmiot.

Należy przy tym zwrócić uwagę, że wyrażona w art. 15 k.p.a. zasada dwuinstancyjności nie określa samodzielnego prawa do zaskarżania w drodze zażalenia wszelkich czynności podejmowanych przez organy administracji publicznej, w tym także udzielanych przez te organy informacji lub wyjaśnień dotyczących okoliczności faktycznych i prawnych mogących mieć wpływ na ustalenie praw i obowiązków jednostki ${ }^{8}$. Wobec tego w postępowaniu wstępnym organ administracji, do którego wniesiono zażalenie, zobowiązany jest między innymi do podjęcia czynności mających na celu ustalenie, czy zażalenie jest dopuszczalne oraz czy zostało wniesione z zachowaniem terminu9 ${ }^{9}$. Ustawa rozgranicza te dwie podstawy prawne rozstrzygnięcia.

5 Zob. np. S. Kasznica, Polskie prawo administracyjne. Pojęcia i instytucje zasadnicze, Poznań 1947, s. 112 n.; a także np. B. Adamiak, Z problematyki właściwości sadów administracyjnych (art. 3 \& 2 pt 4 PostAdmU), „Zeszyty Naukowe Sądownictwa Administracyjnego” 2006, nr 6, s. 7; A. Wiktorowska, [w:] Prawo administracyjne, red. M. Wierzbowski, Warszawa 2009, s. 282-283; zob. również wyrok WSA we Wrocławiu z dnia 5 czerwca 2008 r., III SA/Wr 526/07, LEX nr 514160 .

6 Zob. kryteria rozróżnienia prawnych form działania administracji i ich kwalifikację w opracowaniu M. Zimmermanna w W. Brzeziński, M. Jaroszyński, M. Zimmermann, Polskie prawo administracyjne. Czesść ogólna, Warszawa 1956, s. 320-323. Zob. również J. Borkowski, Decyzja administracyjna, Łódź-Zielona Góra 1998, s. 21.

7 Zob. także np. L. Żukowski, Glosa do postanowienia NSA z dnia 16 lutego 2004 r., OW 2/02, OSP 2005, z. 1, s. 13.

8 Zob. wyrok WSA we Wrocławiu z dnia 21 października 2010 r., II SA/Wr 394/10, LEX nr 755586.

9 Zob. wyrok NSA z dnia 10 marca 2009 r., II OSK 316/08, LEX nr 526409. 
Niedopuszczalność zażalenia może wynikać z przyczyn zarówno o charakterze przedmiotowym, jak i podmiotowym. Przyczyny przedmiotowe obejmują przypadki braku przedmiotu zaskarżenia oraz braku możliwości wniesienia zażalenia na postanowienie $\mathrm{w}$ toku instancji. Zażalenie zatem nie może zostać złożone na postanowienie, które nie weszło do obrotu prawnego (a więc mimo że zostało wydane, nie zostało stronie doręczone lub ogłoszone) lub gdy czynność organu administracji publicznej nie jest postanowieniem, lecz np. czynnością informująca bądź wyjaśniającą ${ }^{10}$. Niedopuszczalność zażalenia z przyczyn o charakterze podmiotowym zachodzi w wypadku wniesienia zażalenia przez podmiot niemający legitymacji do wniesienia tego środka zaskarżenia albo wniesienia zażalenia przez stronę niemającą zdolności do czynności prawnych. Rozpoznanie przez organ drugiej instancji niedopuszczalnego zażalenia oznaczałoby, że rozstrzygnięcie tego organu zostałoby wydane bez podstawy prawnej, przez co zachodziłaby przesłanka stwierdzenia jego nieważności, określona w art. $156 \S 1$ pkt 2 w związku z art. 126 k.p.a.

Właściwy organ administracji, do którego wniesiono zażalenie, w pierwszej kolejności musi dokonać oceny, czy pismo jest podaniem zawierającym zażalenie i czy zażalenie jest dopuszczalne, a następnie bada, czy zostało ono wniesione w terminie i dopiero wówczas ocenia jego zasadność. Negatywny wynik badania wstępnego skutkuje wydaniem jednego z dwóch rozstrzygnięć wymienionych $\mathrm{w}$ art. 134 k.p.a., czyli albo stwierdzenia niedopuszczalności zażalenia (bądź odwołania), albo stwierdzenia uchybienia terminu do wniesienia zażalenia (bądź odwołania). Przepis art. 134 k.p.a. nie wskazuje warunków decydujących o dopuszczalności środka odwoławczego ${ }^{11}$. Przyjęta w art. $134 \mathrm{w}$ związku $\mathrm{z}$ art. 144 k.p.a. kolejność, w jakiej dokonuje się kontroli wymogów formalnych rozstrzygnięcia, ma doniosłe znaczenie prawne. Wyodrębnienie w tej regulacji ustawowej przesłanki terminu do wniesienia środka prawnego i umieszczenie jej w drugiej kolejności wskazuje, że pierwsze czynności organu drugiej instancji powinny koncentrować się na rozstrzygnięciu kwestii dopuszczalności zażalenia (podobnie w przypadku odwołania). Kontrola zachowania terminu do wniesienia zażalenia może nastąpić dopiero w sytuacji pozytywnego wyniku tych czynności, przy czym - stosownie do art. $134 \mathrm{w}$ związku z art. 144 k.p.a. - podejmowane na wstępnym etapie postępowania administracyjnego rozstrzygnięcie ma charakter wyłącznie procesowy i nie rozstrzyga sprawy merytorycznie. Warunkiem przystąpienia do oceny merytorycznej zarzutów zażalenia jest pozytywna ocena organu odnośnie do dopuszczalności zażalenia.

W związku z tym analiza stanu faktycznego przedstawionego w uzasadnieniu głosowanego orzeczenia prowadzi do wniosku, że właściwa była kwalifikacja żądania wnioskodawcy, dokonana przez organ drugiej instancji i następnie przez

10 Zob. wyrok NSA z dnia 16 listopada 2000 r., V SA 235/00, LEX nr 81351.

11 Zob. wyrok WSA w Kielcach z dnia 24 czerwca 2016 r., I SA/Ke 210/16, LEX nr 2084326. 
sądy, ponieważ zakres żądania wnioskodawcy powinien być oceniany i rozpatrywany przez organy zgodnie $\mathrm{z}$ sensem i uzasadnieniem zawartym w piśmie.

Konieczne jest ponowne przytoczenie trafnego spostrzeżenia składu orzekającego Naczelnego Sądu Administracyjnego, że o ile do pism kierowanych do organu administracji publicznej przez stronę można odnosić zasadę ograniczonego formalizmu, o tyle wykładnia aktów administracyjnych nie powinna wychodzić poza językowe znaczenie treści wyrażonej $\mathrm{w}$ dokumencie przez organ. Teza ta nabiera szczególnego znaczenia przy kwalifikowaniu wypowiedzi organu administracji jako indywidualnego aktu administracyjnego (decyzji lub postanowienia).

Konieczne jest przypomnienie, że według art. 124 k.p.a. postanowienie powinno zawierać: oznaczenie organu administracji publicznej, datę jego wydania, oznaczenie strony lub stron albo innych osób biorących udział w postępowaniu, powołanie podstawy prawnej, rozstrzygnięcie, pouczenie, czy i w jakim trybie obowiązuje na nie zażalenie lub skarga do sądu administracyjnego oraz podpis z podaniem imienia i nazwiska, a także stanowiska służbowego osoby upoważnionej do jego wydania. Każdy z wymienionych elementów ma znaczenie w ocenie prawidłowości aktu administracyjnego pod względem proceduralnym i materialnoprawnym ${ }^{12}$. Pismo spełniające wszystkie wskazane w art. 124 k.p.a. wymogi formalne jest postanowieniem ${ }^{13}$. Brak niektórych elementów nie może przesądzać, czy określona czynność organu administracyjnego może być uznana za postanowienie ${ }^{14}$, albowiem strona nie może ponosić konsekwencji wynikających z zaniedbań organu administracji.

Dokonując oceny, czy określone pismo może być kwalifikowane jako postanowienie organu administracji publicznej, należy uwzględnić, że elementem koniecznym do uznania danego aktu organu za postanowienie (albo decyzję) jest rozstrzygnięcie (inaczej osnowa). Brak rozstrzygnięcia w treści postanowienia pozbawia pismo charakteru postanowienia (albo decyzji), albowiem o ile można mówić o wydaniu postanowienia (albo decyzji) bez uzasadnienia, o tyle nie można mówić o wydaniu postanowienia (lub decyzji) bez osnowy. Osnowa jest jednym z zasadniczych i najistotniejszych elementów rozstrzygnięcia administracyjnego, w tym postanowienia. W niej organ administracji wyraża rezultat stosowania normy prawa materialnego i procesowego w odniesieniu do konkretnej sytuacji, z uwzględnieniem konkretnych okoliczności faktycznych oraz prawnych i materiału dowodowego. Treść rozstrzygnięcia jest równoznaczna z udzieleniem,

12 Zob. B. Adamiak, J. Borkowski, Polskie postępowanie administracyjne i sądowoadministracyjne, Warszawa 1996, wyd. 3, s. 171; oraz L. Klat-Wertelecka, B. Kozicka, E. Pierzchała, Decyzja, postanowienie, ugoda w postepowaniu administracyjnym, Wrocław 2014, s. 102-104.

13 Zob. np. W. Dawidowicz, Postępowanie administracyjne. Zarys wykładu, Warszawa 1983, s. 102; oraz J. Jendrośka, [w:] Kodeks postępowania administracyjnego. Komentarz, red. J. Borkowski et al., Warszawa 1989, s. 209.

14 Zob. wyrok NSA z dnia 21 lutego 1994 r., I SAB 54/93, OSP 1995, z. 11, poz. 222. 
bądź nie, stronie uprawnienia albo nałożonym na nią obowiązkiem ${ }^{15}$. Treści rozstrzygnięcia nie można domniemywać. Nie można się także domyślać jej obligatoryjnych części składowych, w tym osnowy ${ }^{16}$. Warunkiem uznania pisma za postanowienie powinno być rozstrzygnięcie o istocie sprawy.

Skoro pismo organu administracji nie odpowiada standardom określonym w art. 124 k.p.a., przez co nie można go zakwalifikować jako postanowienia wydanego w sprawie, a jedynie jako pismo informacyjne, prowadzi to do wniosku, że nie przysługuje na nie zażalenie ${ }^{17}$.

Konsekwencją takiego stanowiska musi być - zgodnie z art. 134 w związku z art. 144 k.p.a. — stwierdzenie niedopuszczalności zażalenia. Postanowienie $\mathrm{w}$ tej sprawie jest ostateczne. Artykuł 134 k.p.a. jest przepisem bezwzględnie obowiązującym ${ }^{18}$.

Oczywiście nie należy obawiać się, że przedstawione, pozornie rygorystyczne procesowo, stanowisko sądu wywoła negatywne skutki dla skarżącego, albowiem w omawianym wyroku słusznie wskazano, że zamiast próby „zaskarżenia” pisma środkami odwoławczymi, wymienionymi w kodeksie postępowania administracyjnego, skarżącemu służą środki, które w ocenie sądu „efektywniej” służą rozwiązaniu sporu prawnego.

Odniesienie się do tej części glosowanego wyroku wymaga jednak dokonania pewnych uwag natury ogólnej. Przede wszystkim nie można zapominać o ewolucji przepisów procesowych zawartych w kodeksie postępowania administracyjnego, a także - co ma tutaj istotne znaczenie — przepisów normujących procedurę sądowoadministracyjną, ze szczególnym uwzględnieniem zakresu właściwości sądów administracyjnych. Należy dostrzec, że prawodawca stworzył rozbudowany, lecz zasadniczo koherentny system instytucji prawnych mających służyć ochronie interesu prawnego (a w wypadkach w ustawie określonych ${ }^{19}$ również interesu faktycznego) jednostki, w szczególności w ramach administracyjne-

15 Zob. np. Komentarz do art. 124 k.p.a., [w:] Kodeks postępowania administracyjnego. Komentarz, red. R. Hauser, M. Wierzbowski, wyd. 2, Warszawa 2015, Legalis/el.

16 Zob. wyrok WSA w Warszawie z dnia 21 czerwca 2005 r., II SA/Wa 223/05, LEX 171676.

17 Zob. wyrok NSA z dnia 15 października 2009 r., I OSK 22/09, Legalis.

18 Zob. wyrok NSA z dnia 16 listopada 2000 r., V SA 235/2000, LEX nr 81351.

19 Przykład: zgodnie z art. 1 ust. 2 pkt 4 ustawy z dnia 26 marca 1982 r. o scalaniu i wymianie gruntów (tekst jedn. Dz.U. z 2014 r. poz. 700 z późn. zm.) przez „właściciela” rozumie się także posiadacza samoistnego. Zarówno w doktrynie, jak i orzecznictwie SN przyjmuje się, że posiadacz gruntu (bez tytułu prawnego) po zamianie go w wyniku scalenia na nową działkę gruntu kontynuuje posiadanie (zob. uchwałę SN z dnia 20 lutego 2013 r., III CZP 98/12, OSNIC 2013, nr 9, poz. 105). Według art. 4 pkt 4 ustawy z dnia 3 lutego 1995 r. o ochronie gruntów rolnych i leśnych (tekst jedn. Dz.U. z 2015 r. poz. 909 z późn. zm.) ilekroć w ustawie jest mowa o właścicielu, rozumie się przez to również posiadacza samoistnego, zarządcę lub użytkownika, użytkownika wieczystego i dzierżawcę. 
go postępowania jurysdykcyjnego ${ }^{20}$. W skład powyższego systemu wchodzą nie tylko środki zaskarżenia na indywidualne akty administracyjne, lecz także - co na tle komentowanych tez sądu ma szczególne znaczenie — środki umożliwiające zwalczanie wszelkich form bezczynności organów administracyjnych. Co istotne, środki te mają obecnie szeroki zakres zastosowania, albowiem pozwalają na ochronę zarówno przed sformalizowanymi aktami administracyjnymi, jak i czynnościami materialno-technicznymi ${ }^{21}$.

Można zatem przyjąć założenie, że niezależnie od tego, czy organ administracyjny określa sytuację prawną jednostki aktem administracyjnym albo czynnością niesformalizowaną lub też pozostaje w bezczynności w wydaniu aktu lub czynności, podmiotowi przeważnie przysługuje adekwatny środek prawny służący ochronie jego interesu (prawnego lub w wypadkach wskazanych przez ustawodawcę - faktycznego). Ważne jest przy tym zastrzeżenie, że jest to środek prawny, którego treść jest adekwatna do formy naruszenia interesu. Przy tym korelatem środków zaskarżenia na akty i czynności jest rozbudowany system środków zwalczania bezczynności i przewlekłego postępowania choćby z tego wzglę$\mathrm{du}$, że prawo procesowe, pełniąc funkcję służebną wobec prawa materialnego, ma pełnić podstawową funkcję $\mathrm{w}$ płaszczyźnie pożądanych skutków społecznych przez ochronę praw jednostki ${ }^{22}$.

Podsumowując, trzeba zatem stwierdzić, że niezależnie od tego, czy organ administracyjny narusza interes działaniem, czy też milczeniem bądź przewlekłością, jednostka powinna znaleźć określony, stypizowany przez prawodawcę, środek ochrony prawnej (odwołanie, zażalenie, zażalenie na bezczynność, skarga do sądu, itp.). Chodzi zatem o instytucję, której istota i funkcja są dostosowane do określonej sytuacji procesowej.

Zbędne jest więc pochopne przydawanie pismu informującemu treści indywidualnego aktu administracyjnego. Należy podkreślić, że byłoby to jedynie

20 Zob. np. L. Klat-Wertelecka, Bezczynność organu administracji publicznej w postępowaniu administracyjnym $w$ dobie europeizacji prawa, [w:] Europeizacja polskiego prawa administracyjnego, red. Z. Janku et al., Wrocław 2005, s. 485-494; B. Adamiak, Od klasycznych do współczesnych gwarancji prawa do szybkiego załatwienia sprawy administracyjnej, [w:] Między tradycja a przyszłościa w nauce prawa administracyjnego. Ksiegga jubileuszowa dedykowana Profesorowi Janowi Bociowi, red. J. Superat, Wrocław 2009, s. 17-27.

${ }^{21}$ Por. np. ewolucję zakresu ochrony sądowo-administracyjnej wynikającej kolejno z przepisów: art. 196 ustawy z dnia 14 czerwca 1960 r. - Kodeks postępowania administracyjnego (tekst jedn. Dz.U. z 1980 r. Nr 26, poz. 9 z późn. zm.); art. 16-17 ustawy z dnia 11 maja 1995 r. o Naczelnym Sądzie Administracyjnym (Dz.U. z 1995 r. Nr 74, poz. 368 z późn. zm.); a następnie art. 3 ustawy z dnia 30 sierpnia 2002 r. - Prawo o postępowaniu przed sądami administracyjnymi (tekst jedn. Dz.U. z 2016 r. poz. 718 z późn. zm.).

22 Tego rodzaju funkcję prawa procesowego wyróżniono w doktrynie — zob. B. Adamiak, Administracja publiczna pod rzadami prawa a rozporzadzalność jednostki prawem do obrony, [w:] Administracja publiczna pod rządami prawa: księga pamiątkowa z okazji 70-lecia urodzin prof. zw. dra hab. Adama Błasia, red. J. Korczak, Wrocław 2016, s. 21. 
pozorne realizowanie ochrony interesu prawnego jednostki. Przedmiotem potencjalnej kontroli instancyjnej w postępowaniu zażaleniowym byłby przecież akt formalnie ułomny, który nie spełnia kryteriów formalnych z art. 124 k.p.a. Oprócz wyraźnie oznaczonego rozstrzygnięcia brakowałoby czytelnego uzasadnienia czy też pouczenia o środkach zaskarżenia. To z kolei niweczyłoby możliwość prawidłowej realizacji postępowania odwoławczego, zażaleniowego czy też sądowoadministracyjnego $0^{23}$.

Właśnie dlatego sąd w glosowanym wyroku stwierdził, że odstąpienie przez organ administracyjny od wydania prawidłowego rozstrzygnięcia (postanowienia o odmowie wszczęcia postępowania) stanowi podstawę do „wymuszenia na nim” wydania „wymaganego" aktu procesowego (oczywiście wymaganego co formy oraz zawierającego obligatoryjne elementy struktury) poprzez wystąienie z odpowiednim środkiem prawnym przeciwdziałającym niezgodnemu z prawem działaniu organu administracji publicznej — złożeniem zażalenia do organu wyższego stopnia (art. 37 § 1 k.p.a.), a następnie skargi na bezczynność do sądu administracyjnego (art. $3 \S 2$ pkt 8 ustawy z dnia 30 sierpnia 2002 r. — Prawo o postępowaniu przed sądami administracyjnymi ${ }^{24}$ ). Są to - co jeszcze raz należy podkreślić — po prostu środki prawne obiektywnie efektywne z punktu widzenia potrzeby ochrony jego interesu prawnego.

Na koniec warto zadać pytanie, czy przyjęcie omawianej tezy NSA oznacza odejście od głęboko zakorzenionego, zarówno w doktrynie, jak i orzecznictwie, zapatrywania, że o charakterze danej czynności procesowej lub kwalifikacji aktu nie decyduje forma, lecz jego merytoryczna treść ${ }^{25}$. Chodzi zatem o przyjęcie domniemania decyzji (albo postanowienia) dla wypowiedzi organu administracji

${ }^{23}$ Zob. np. rozważania na temat znaczenia prawidłowego uzasadnienia aktu indywidualnego: Z. Janowicz, Kodeks postepowania administracyjnego. Komentarz, Warszawa 1987, s. 243-244.

24 Tekst jedn. Dz.U. z 2016 r. poz. 718 z późn. zm.

$25 \mathrm{~W}$ doktrynie podniesiono, że w przypadku nieokreślenia wprost w normach materialnego prawa administracyjnego formy konkretyzacji praw i obowiązków jednostki może mieć zastosowanie domniemanie formy decyzji administracyjnej. Konkluzja co do formy czynności organu administracji publicznej wymaga przeprowadzenia procesu wykładni prawa, uwzględniającej szereg wartości istotnych w demokratycznym państwie prawnym, a zatem nie może być oparta wyłącznie na wykładni językowej (zob. B. Adamiak, Zagadnienie domniemania formy decyzji administracyjnej, [w:] Podmioty administracji publicznej i prawne formy ich działania. Studia i materiaty z konferencji naukowej poświęconej jubileuszowi 80-tych urodzin Profesora Eugeniusza Ochendowskiego, Toruń 2005, s. 15). Domniemanie formy decyzji administracyjnej jest dopuszczalne, jeżeli istnieją normy administracyjnego prawa materialnego, które określają treść działania organu administracji publicznej. Domniemanie formy decyzji administracyjnej nie obejmuje bowiem domniemania podstaw działania organu administracji publicznej (ibidem, s. 17). Ponadto przyjęcie domniemania decyzji administracyjnej powinno być uzasadnione pewnymi wartościami, np. sprawnym wykonywaniem zadań administracji publicznej czy ochroną praw jednostki przez zapewnienie jej prawa do procesu i prawa do sądu (ibidem, s. 8, 16). 
publicznej ${ }^{26}$, mającego cechy konstytutywne aktu administracyjnego, takie jak: oznaczenie organu administracji publicznej, wydającego akt, oznaczenie adresata, sformułowanie rozstrzygnięcia oraz podpis osoby upoważnionej do wydania aktu.

$\mathrm{Na}$ tak postawione pytanie jednoznaczną odpowiedź znajdujemy w uzasadnieniu omawianego wyroku, z którego wynika, że przyjmowanie domniemania działania organu w formie procesowej (decyzji/postanowienia) zwiększa sferę przyznawanej stronie ochrony, jednak nie może to stać w sprzeczności z ujawnioną wolą organu i jednoznaczną treścią podjętej czynności urzędowej. Rozwijając powyższą myśl, można dodać jeszcze, że tylko wtedy, gdy organ administracyjny lub sąd dostrzeże brak możliwości zastosowania adekwatnego, a co najważniejsze - efektywnego środka ochrony interesu jednostki, konieczne jest przyjmowanie możliwości skarżenia aktu administracyjnego niespełniającego kryteriów art. 107 czy też art. 124 k.p.a. ${ }^{27}$

Oznacza to, że przyjęcie domniemania działania organu w formie procesowej (decyzji/postanowienia) jako wyjątku od obowiązku przestrzegania rygoryzmu

${ }^{26} \mathrm{~W}$ początkowym okresie orzecznictwo NSA skłaniało się ku możliwie szerokiemu postrzeganiu różnych wypowiedzi organów administracji publicznej jako decyzji (bez względu na ułomności tychże wypowiedzi — zob. np. wyrok NSA z dnia 20 lipca 1981 r., SA 1163/81, OSPiKA 1982, nr 9-10, poz. 169, akceptowany przez J. Borkowskiego, [w:] B. Adamiak, J. Borkowski, Kodeks postępowania administracyjnego. Komentarz, Warszawa 2011, s. 425-426, nb 4; a także wyrok NSA z dnia 25 lutego 1983 r., II SA 2083/82, ONSA 1983, nr 1, poz. 14. Należy zauważyć, że zakres kontroli sądowej do roku 1990 ograniczony był głównie do rozpatrywania skarg na decyzje administracyjne, i to nie wszystkie — zob. T. Woś, Postępowanie sądowoadministracyjne, Warszawa 1996, s. 34-37; J. Świątkiewicz, Naczelny Sąd Administracyjny. Komentarz do ustawy, Warszawa 2001, s. 85, uw. 1. W nawiązaniu do tych poglądów w orzecznictwie i piśmiennictwie do dzisiaj przyjmuje się, że z art. 104 k.p.a. można wyprowadzić kompetencję organu do wydania decyzji administracyjnej w każdej sprawie wymagającej rozstrzygnięcia, chyba że przepis prawa wyraźnie wyłącza możliwość wydania decyzji — zob. K.M. Ziemski, Indywidualny akt administracyjny jako forma działania administracji, Poznań 2005, s. 445-453; C. Martysz, Podstawa prawna decyzji administracyjnej, [w:] Księga jubileuszowa z okazji 60 rocznicy urodzin Profesora Ernesta Knosali, red. G. Łaszczyca, A. Matan, L. Zacharko, Warszawa 2008, s. 209-216; zob. również uchwałę NSA z dnia 28 maja 2001 r., OPK 10/01, ONSA 2001, nr 4, poz. 159; oraz postanowienie NSA z dnia 27 listopada 2015 r., I OSK 2741/15, LEX nr 1989907; wyrok NSA z dnia 3 sierpnia 2016 r., I OSK 3373/15, LEX nr 2118767.

27 Zob. B. Adamiak i J. Borkowski, Glosa do wyroku NSA z dnia, I SAB 54/93, OSP 1995, nr 11, poz. 222. Autorzy w powołanej glosie podkreślili, że przyjęcie tezy, iż o istocie aktu prawnego powinna przesądzać jego treść, a nie forma ,poszerza w praktyce zakres sądowej kontroli administracji publicznej, zwiększając liczbę przypadków, w których jednostka może ją uruchomić swoją skargą”. Należy jednak przypomnieć, że glosowany wyrok dotyczył skargi do NSA na bezczynność organu administracyjnego w wydaniu decyzji administracyjnej w związku z wnioskiem o stwierdzenie nieważności decyzji. Przy tym wypowiedź organu administracyjnego, której dotyczył wniosek o stwierdzenie nieważności, nie przybrała procesowej formy decyzji. Tymczasem, jak wskazano w uzasadnieniu glosowanego wyroku NSA z dnia 21 lutego 1994 r., „od odpowiedzi na pytanie, czy pismo to jest decyzją administracyjną, zależy zasadność skargi”. Innymi słowy — przyjęcie na tle rozpoznawanej wówczas sprawy w 1994 r. materialnego charakteru decyzji było jedyną możliwością merytorycznego udzielenia skarżącemu ochrony w postępowaniu sądowo-administracyjnym. 
procesowego co do formy aktu administracyjnego nie może być nadużywane. Powinno ono być raczej stosowane jako środek ostateczny, ultima ratio, gdy nie ma innych możliwości zapewnienia ochrony prawnej jednostce domagającej się ochrony swojego interesu przed organem administracyjnym lub sądem.

\section{Bibliografia}

Adamiak B., Administracja publiczna pod rządami prawa a rozporządzalność jednostki prawem do obrony, [w:] Administracja publiczna pod rządami prawa: księga pamiatkowa z okazji 70-lecia urodzin prof. zw. dra hab. Adama Błasia, red. J. Korczak, Wrocław 2016.

Adamiak B., Od klasycznych do wspótczesnych gwarancji prawa do szybkiego załatwienia sprawy administracyjnej, [w:] Między tradycja a przyszłościq w nauce prawa administracyjnego. Księga jubileuszowa dedykowana Profesorowi Janowi Bociowi, red. J. Superat, Wrocław 2009.

Adamiak B., Zagadnienie domniemania formy decyzji administracyjnej, [w:] Podmioty administracji publicznej i prawne formy ich dziatania, Studia i materiały z konferencji naukowej poświęconej jubileuszowi 80-tych urodzin Profesora Eugeniusza Ochendowskiego, Torun 2005.

Adamiak B., Z problematyki właściwości sądów administracyjnych (art. 3 \& 2 pkt 4 PostAdmU), „Zeszyty Naukowe Sądownictwa Administracyjnego” 2006, nr 6.

Adamiak B., Borkowski J., Glosa do wyroku NSA z dnia, I SAB 54/93, OSP 1995, nr 11, poz. 222.

Adamiak B., Borkowski J., Polskie postępowanie administracyjne i sądowoadministracyjne, wyd. 3, Warszawa 1996.

Borkowski J. [w:] Adamiak B., Borkowski J., Kodeks postępowania administracyjnego. Komentarz, Warszawa 2011.

Borkowski J., Decyzja administracyjna, Łódź-Zielona Góra 1998.

Dawidowicz W., Postępowanie administracyjne. Zarys wykładu, Warszawa 1983.

Janowicz Z., Kodeks postepowania administracyjnego. Komentarz, Warszawa 1987.

Jendrośka J. [w:] Kodeks postępowania administracyjnego. Komentarz, red. J. Borkowski, J. Jendrośka, R. Orzechowski, A. Zieliński, Warszawa 1989.

Kasznica S., Polskie prawo administracyjne. Pojęcia i instytucje zasadnicze, Poznań 1947.

Klat-Wertelecka L., Bezczynność organu administracji publicznej w postepowaniu administracyjnym $w$ dobie europeizacji prawa, [w:] Europeizacja polskiego prawa administracyjnego, red. Z. Janku, Z. Leoński, M. Szewczyk, M. Waligórski, K. Wojtczak, Wrocław 2005.

Klat-Wertelecka L., Kozicka B., Pierzchała E., Decyzja, postanowienie, ugoda w postęowaniu administracyjnym, Wrocław 2014.

Kodeks postępowania administracyjnego. Komentarz, red. R. Hauser, M. Wierzbowski, wyd. 2, Warszawa 2015.

Martysz C., Podstawa prawna decyzji administracyjnej, [w:] Ksiegga jubileuszowa z okazji 60 rocznicy urodzin Profesora Ernesta Knosali, red. G. Łaszczyca, A. Matan, L. Zacharko, Warszawa 2008.

Świątkiewicz J., Naczelny Sąd Administracyjny. Komentarz do ustawy, Warszawa 2001.

Wiktorowska A. [w:] Prawo administracyjne, red. Wierzbowski M., Warszawa 2009.

Woś T., Postepowanie sądowoadministracyjne, Warszawa 1996.

Ziemski K.M., Indywidualny akt administracyjny jako forma działania administracji, Poznań 2005.

Zimmermann M. [w:] W. Brzeziński, M. Jaroszyński, M. Zimmermann, Polskie prawo administracyjne. Część ogólna, Warszawa 1956 


\title{
Gloss to the judgment of the Supreme Administrative Court of 19 July 2016, files no. II OSK 2762/14
}

\begin{abstract}
Summary
The study presents the judgment of the Supreme Administrative Court of 19 July 2016, II OSK $2762 / 14$, and acceds to the position of the Court. It was explained that on the grounds of the judgment commented, reference is made to the two essentials of general procedural issues, pointing — first — on the eligibility criteria letters sent by the administration to the applicant, and secondly - the basis to force the administration authority issuing the required procedural act. It was pointed out that regardless of whether the administrative authority violates the interests of action, or silence or protraction, an entity shall find a specific remedy standardized by the legislature (appeal, complaint, complaint for failure to act, the complaint to the court, etc.). It is, therefore, a authority whose essence and, at the same time, the function is tailored to the specific situation of the process.
\end{abstract}

Keywords: administrative procedure, inactivity of the administration, complaint to the court. 